\title{
The Fourier transform infrared spectroscopy from Diplazium esculentum and Rivina humilis analysis to reveals the existence of necessary components in oil palm plantations of Ganoderma boninense control
}

\author{
WISMAROH SANNIWATI SARAGIH ${ }^{1}$, EDISON PURBA ${ }^{2, \bullet}$, LISNAWITA $^{2}$, MOHAMMAD BASYUNI ${ }^{3}$ \\ ${ }^{1}$ Doctoral Program in Agricultural Science, Faculty of Agriculture, Universitas Sumatra Utara. Jl. Prof. Dr. A. Sofian No. 3, Kampus USU Padang Bulan, \\ Medan 20155, North Sumatra, Indonesia. Tel.: +62-61-8213236, Fax.: +62-61-8211924, `email: edisonpurba @usu.ac.id \\ ${ }^{2}$ Program of Agrotechnology, Faculty of Agriculture, Universitas Sumatra Utara. Jl. Prof. Dr. A. Sofian No. 3, Kampus USU Padang Bulan, Medan \\ 20155, North Sumatra, Indonesia \\ ${ }^{3}$ Department of Forestry, Faculty of Forestry, Universitas Sumatra Utara. Jl. Tri Dharma Ujung No. 1 Kampus USU Padang Bulan Medan 20155, North \\ Sumatra, Indonesia
}

Manuscript received: 15 May 2021. Revision accepted: 3 August 2021.

\begin{abstract}
Saragih WS, Purba E, Lisnawita, Basyuni M. 2021. The Fourier transform infrared spectroscopy from Diplazium esculentum and Rivina humilis analysis reveals necessary components in oil palm plantations of Ganoderma boninense control. Biodiversitas 22 : 3645-3651. The Fourier transform infrared spectroscopy (FTIR) has been widely utilized for biological samples and biomolecular characterization. We aim to identify Ganoderma boninense through FTIR and obtain a functional group that can facilitate early basal stem rot detection. Here, positive control (KP) was not inoculated with $G$. boninense and negative control (KN) was inoculated with $G$. boninense. However, the treatment samples, Diplazium esculentum leaf extract, Rivina humilis leaf extract, and fungicide treatment, were not inoculated with $G$. boninense. The positive control oil-palm leaf samples exhibited spectral bands similar to those in the $D$. esculentum extract, $R$. humilis extract, and fungicide treatment. Strong bonds were observed at wavelengths $3379 \mathrm{~cm}^{-1}, 2927 \mathrm{~cm}^{-1}, 1639$ $\mathrm{cm}^{-1}$, and $1056 \mathrm{~cm}^{-1}$. Others were moderate to weak, except the negative control samples with strong bonds at $2044 \mathrm{~cm}^{-1}$. This indicates amine $\mathrm{N}-\mathrm{H}$ functional groups, alkane functional group $\mathrm{C}-\mathrm{H}$, functional group alkene $\mathrm{C}=\mathrm{C}, \mathrm{C}-\mathrm{O}$, functional group ester, and functional group isothiocyanate $\mathrm{N}=\mathrm{C}=\mathrm{S}\left(\mathrm{C}_{4} \mathrm{H}_{5} \mathrm{NS}\right.$ or $\left.\mathrm{CH}_{2}=\mathrm{CHCH}_{2} \mathrm{~N}=\mathrm{C}=\mathrm{S}\right)$. The FTIR plot result denotes $G$. boninense through $\mathrm{N}=\mathrm{C}=\mathrm{S}$ Isothiocyanate functional group presence at $2140-1990 \mathrm{~cm}^{-1}$. This unique structure is only found in infected oil-palm leaf tissues of $G$. boninense. Our study suggests that FTIR spectroscopy is more beneficial than conventional methods in early detection of G. boninense infection in oil palm.
\end{abstract}

Keywords: Diplazium esculentum, Ganoderma boninense, oil palm, Rivina humilis

Abbreviations: BSR: Basal Stem Rot; FTIR: Fourier Transform Infrared

\section{INTRODUCTION}

Oil palm plantations are the world's largest agricultural plantations, with Indonesia leading oil palm production, followed by Malaysia (Mohd et al. 2020). With a total export value of Rp. 304 trillion, oil palm plantations contribute significantly to the Indonesian economy (Junaidi, 2020). Furthermore, according to BPS-Statistics Indonesia (2020), oil palm plantations span 14,724 million hectares, with 45,861 million tons of oil palm produced in 2019 alone. This number rose to 14,996 million hectares in 2020 (49,117 million tons). However, the G. boninense fungus, which causes Sal stem rot, threatens the expansion of oil palm production (Hashim et al. 2021).

Weeds contain various phytochemical compounds, such as coumarins, flavonoids, phenolics, etc., which exhibit antifungal activity and can be isolated (Gadisa and Tadesse, 2021). As such, carotenoids, phenolics (containing nitrogen, i.e., alkaloids), amines, and organosulfur compounds (isothiocyanate and allyl sulfide) are among the phytochemicals categorized according to their chemical characteristics and functional groups (Mitsiogianni et al. 2019). For example, when $D$. esculentum is extracted with medium ethanol, the secondary flavonoid metabolite components are 110.8 11.12; however, when extracted with water, the flavonoid content is $16.2 \pm 0.7$ (Tongco et al. 2014). As an antifungal, $R$. humilis contains $\mathrm{n}$-Hexadecanoic acid, Hexadecanoic acid, and 1(hydroxymethyl)-1,2-ethenyl ester (Kavita and Mary, 2020). In light of this, through gas chromatographymass spectroscopy (GC-MS) analysis, the bioactivity of hexadecanoic acid, methyl ester, and 1Heneicosanol chemical compound as an antifungal were investigated in vitro against Candida albicans fungus. Such plant secondary metabolites can be applied to control oil palm trunk rot since they contain natural ingredients and do not pollute the environment (Suprapta, 2016).

The G. boninense pathogen causes BSR, which infects young and old (15 years) plants (Priwiratama et al. 2020) and decreases over $50 \%$ of production (Susanto, 2011). 
Despite numerous efforts, this disease is difficult to control (Viera-Torres et al. 2020) due to its detection delay (Cooper et al. 2011). Moreover, the rotting stem is always asymptomatic and emerges only at the final infection stage when over half the root tissue has decomposed, leading to plant death.

Thus, early detection methods are urgently required. Only a few methods have been reported to detect this disease before symptoms manifest as fruiting bodies, including enzyme-linked immunosorbent assay (ELISA) (Kayalvizhi and Antony, 2011; Utomo and Niepold, 2000; Kandan et al. 2009; Siddiqui et al. 2021), polymerase chain reaction (PCR) (Chong et al. 2011; Midot et al. 2019; Bahari et al. 2018; Goh et al. 2016), sequencing (Hayati and Basyuni, 2019), laser machine learning (ML) through laser beam scanning (Husin et al. 2020), hyperspectral imagery visible near-infrared (VIS-NIR) (Azmi et al. 2020; Ahmadi et al. 2017; Isha et al. 2019), scanning electron microscopy (Alexander et al. 2017), and network detection through Ganoderma selective media (GSM) network (Rakib et al. 2014; Darus and Seman, 1992; Penido et al. 2013). Furthermore, weeds as markers of the organism's presence based on dominant species have also been reported (Saragih and Purba, 2018), with the nutrients in weed leaves compared to infected and uninfected oil palm (Saragih and Purba, 2019). However, this method is expensive and time-consuming for large-scale applications.

Ganoderma FTIR quantification detection reported (Alexander et al. 2014) success in detecting $G$. boninense through different functional groups in healthy oil palms. Detection using FTIR reported (Liaghat et al. 2014) that samples prepared with $\mathrm{KBr}$ with linear discriminant analysis (LDA) based models yielded the highest mean overall classification accuracy of $92 \%$, with individual classification accuracy greater than about $90 \%$ using the raw dataset and verifying spectroscopic potential midinfrared for detection of Ganoderma in early stages of asymptomatic infection in oil palm. FTIR detects blast disease in rice by absorbing chemical groups with differences in fat and cutin content, which increases due to infection (Gaoqiang et al. 2020). The physiological measurements of leaves showed differences between control and plants that were given $\mathrm{NaCl}$, and biochemical changes that occurred in functional groups were detected using FTIR-ATR (attenuated total reflectance) spectroscopy (Westworth et al. 2019). However, there are no reports regarding the detection of this organism's control through the administration of $D$. esculentum, $R$. humilis secondary metabolite compounds, and fungicides. Furthermore, the detection and identification of microorganisms using FTIR spectroscopy are promising due to their sensitivity, speed, low cost, and simplicity (Salman et al. 2010). We thus aimed to identify $G$. boninense through FTIR and obtain a functional group as an indicator in the early detection of BSR in infected and treated oil palms.

\section{MATERIALS AND METHODS}

\section{Plant materials}

Oil palm seedling plant material crossing Dura $\mathrm{x}$ Pisifera is tolerant of the $G$. boninense (isolate NJ72 TG 147) from the PT Socfindo collection. The isolates of the fungus $G$. boninense inoculated in oil palm seedlings were reported molecularly in the Socfindo plant disease laboratory (Purba et al. 2020). Furthermore, D. esculentum leaves were collected from PT. PP. London Sumatra, Tbk Langkat area, North Sumatra position $3^{\circ} 26^{\prime} 02,38^{\prime \prime} \mathrm{N}$ and $98^{\circ} 12^{\prime} 56,67^{\prime}$ 'E, while the $R$. humilis leaves were obtained from Deli Serdang area, North Sumatra position $3^{\circ} 28^{\prime} 08,23$ ' $\mathrm{N}$ and $98^{\circ} 49^{\prime} 04,11^{\prime \prime} \mathrm{E}$.

Figure 1 presents the locations where D. esculentum and $R$. humilis leaves were collected. These plants are unique since they are considered weeds in oil palm plantations, but $D$. esculentum is consumed as a young leafy vegetable and sold to consumers, indicating that it has certain commercial value. Due to its abundance in the plantation area, it can be marketed and employed as a source of additional revenue. D. esculentum is also an additional source of income since it is consumed as a vegetable and thrives in a humid climate with humidity levels ranging from $65-80 \%$ and a high annual rainfall of $2,205.43 \mathrm{~mm}$. $R$. humilis found in plantation areas is a unique weed species. Additionally, suppose the oil palm dies as a result of the invasion of $G$. boninense. In that case, the $R$. humilis species thrive and take over the surrounding region since the humidity and organic matter are suitable for their growth.

\section{Procedures}

The FTIR analysis was conducted in the Faculty of Pharmacy, University of Sumatera Utara, Medan, Indonesia, and the research was conducted in the greenhouse of the university's Faculty of Agriculture. This method of producing weed leaf involved the application of ethanol extract to the crop, as described by Rattanata et al. (2014). The modified extract was applied to the oil palm seedlings maintained in the greenhouse without fertilizer. The plants were treated with extracts from metabolite compounds of $D$. esculentum (DE), R. humilis (RE), and pyraclostrobin fungicide, each amounting to a volume of $50 \mathrm{~mL}$ (Said et al. 2019; Rebitanim et al. 2020; Bivi et al. 2016). Plants as positive (healthy plant, not inoculated with $G$. boninense) and negative controls (inoculated with $G$. boninense but without treatment) were included to perform a comparison (Idris et al. 2006). Each treatment consisted of three replicates.

The seedlings indicated that BSR disease progressed after five months of inoculation, but the only symptom of the disease was the color of the infected leaves, which were yellowing (Figure 2). The FTIR analysis used five plant samples from each treatment: healthy plants (KP), infected $(\mathrm{KN})$, D. esculentum extract, $R$. humilis, and a comparison synthetic fungicide. Furthermore, oil palm leaves were taken from the base leaves, middle leaves, and leaves near the shoots that had not opened yet. They were brought to the laboratory and thoroughly washed with running water 
to remove the impurities. Then, the leaves were crushed with liquid nitrogen into a fine powder (Khan et al. 2021) and the FTIR was performed by the $\mathrm{KBr}$ pellet method (Lai et al. 2021). The spectrum was adjusted at $4 \mathrm{~cm}^{-1}$ and the scanning range was selected between $400 \mathrm{~cm}^{-1}$ to $4000 \mathrm{~cm}^{-1}$ (Alexander et al. 2014). Subsequently, analysis was conducted on a total of $0.0020 \mathrm{~g}$ of samples and $0.1980 \mathrm{~g}$ $\mathrm{KBr}$, which was smoothed and printed onto thin or transparent plates utilizing the Shimadzu tool (IRPrestige21 ). The resulting chromatograms were compared to the IR Table (Lai et al. 2021).

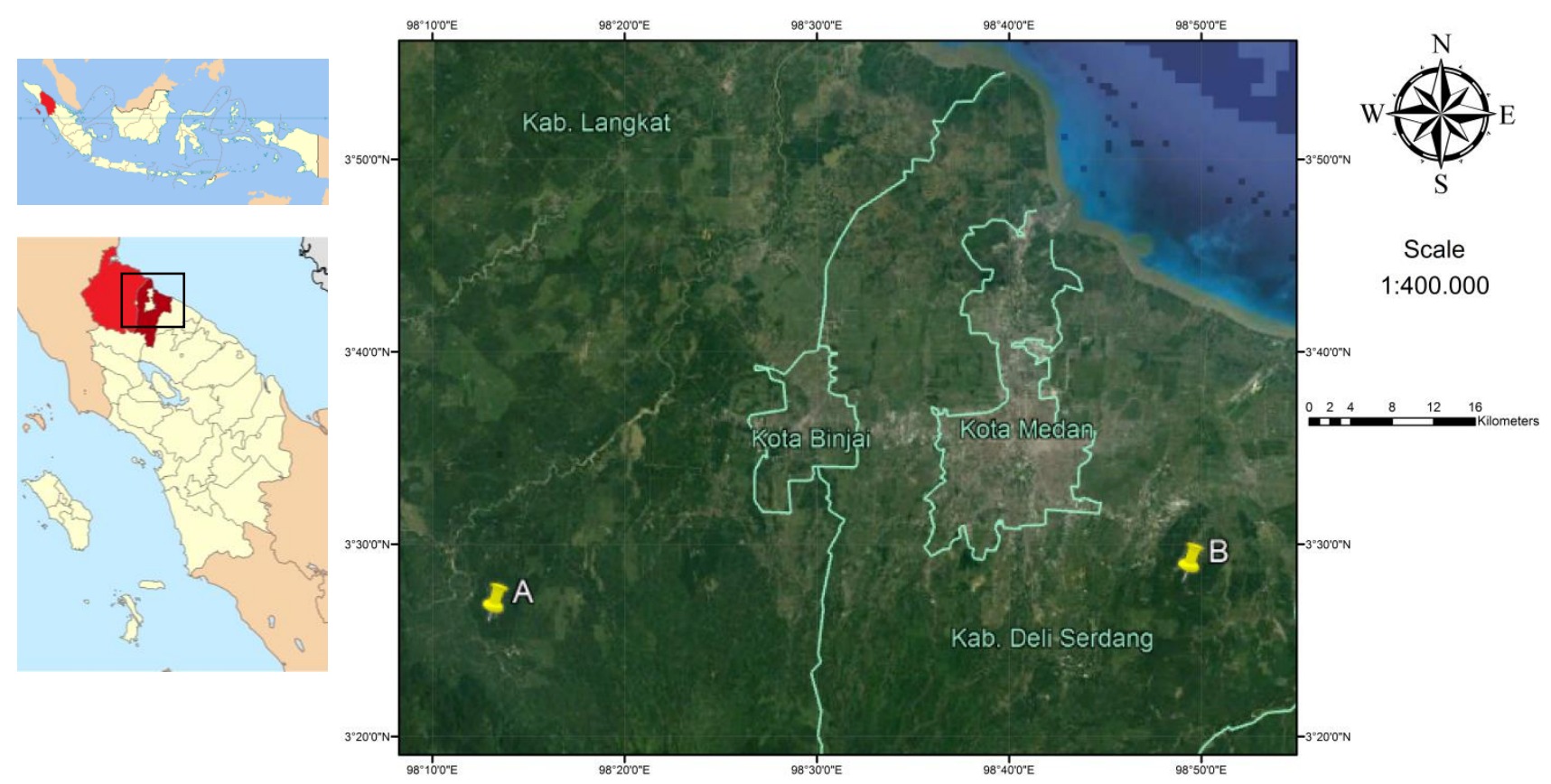

Figure 1. Map of weed collection locations: A. Diplazium esculentum leaves, B. Rivina humilis leaves in PT. PP. London Sumatra, Tbk, North Sumatra Province, Indonesia

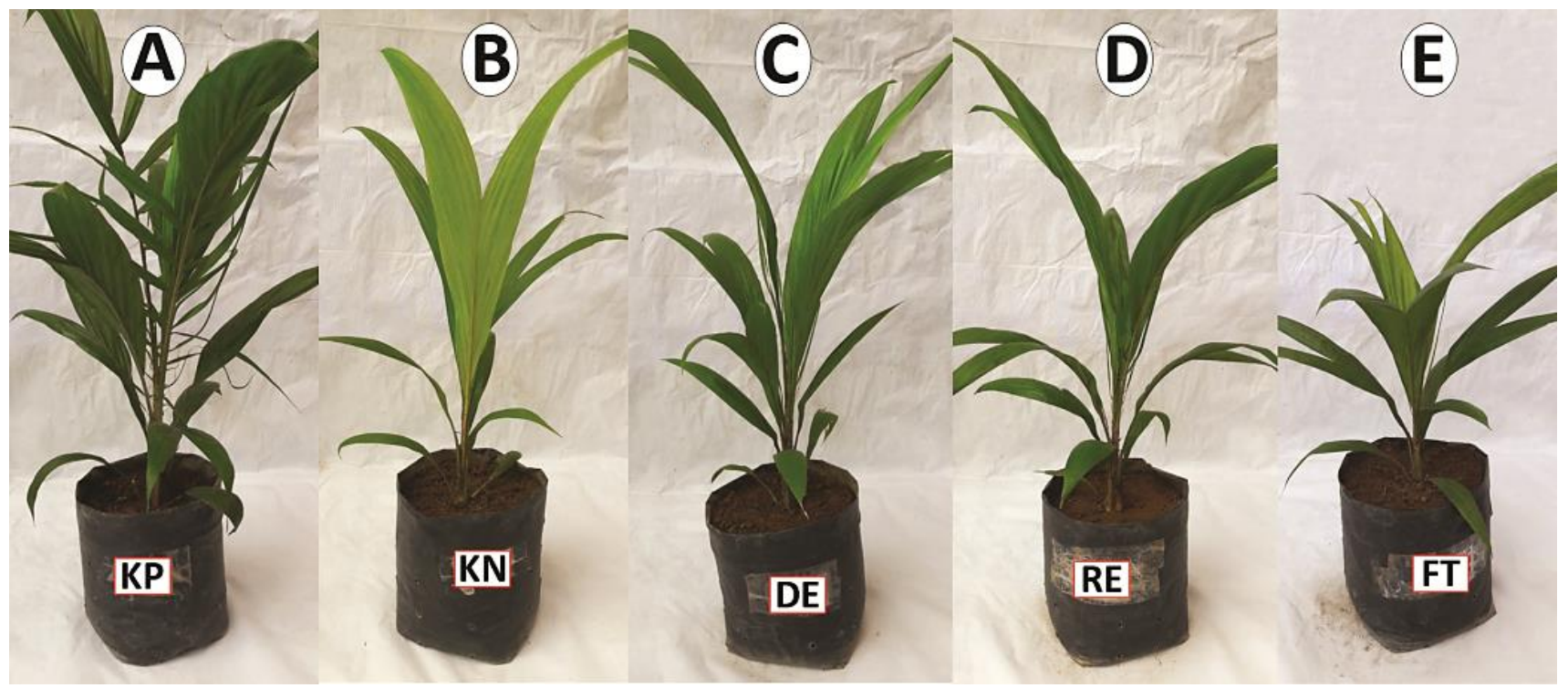

Figure 2. Oil palm seedlings three months after treatment. A. Healthy; B. Infected; C. Diplazium esculentum extract; D. Rivina humilis extract; and E. Treatment fungicides 


\section{RESULTS AND DISCUSSION}

\section{Results}

The FTIR demonstrated the oil palm functional group compounds after inoculation and treatment by the secondary metabolite extracts of $D$. esculentum and $R$. humilis that utilized the oil palm leaf extract (Figure 3). FTIR was applied to obtain biomarker spectroscopy from oil palm leaves and screening to detect and identify the differences in the functional groups that played a significant role in controlling $G$. boninense. The positive control oil palm leaf samples spectrum was similar to that of the D. esculentum leaf extract, $R$. humilis leaf extract, and the fungicide treatment. There was no difference in the spectral band, as illustrated in Figure 3. Strong bonds were observed at wavelengths $3379 \mathrm{~cm}^{-1}, 2927 \mathrm{~cm}^{-1}, 1639 \mathrm{~cm}^{-1}$, and $1056 \mathrm{~cm}^{-1}$, while the others varied moderately to weakly, except for the negative control leaf sample with strong bonds at the wavelength $2044 \mathrm{~cm}^{-1}$. This indicated the presence of the following functional groups: $\mathrm{N}-\mathrm{H}$ (amine, C-H (alkane), $\mathrm{C}=\mathrm{C}$ (alkene), $\mathrm{C}-\mathrm{O}$ (ester), and $\mathrm{N}=\mathrm{C}=\mathrm{S}$ (isothiocyanate). The molecular formula of the compound is $\mathrm{C}_{4} \mathrm{H}_{5} \mathrm{NS}$ or $\mathrm{CH}_{2}=\mathrm{CHCH}_{2} \mathrm{~N}=\mathrm{C}=\mathrm{S}$. Tiznadohernández (2008) reported that, in vitro, the isothiocyanate functional group $(\mathrm{N}=\mathrm{C}=\mathrm{S})$ was able to react with an amino group from an amino acid and formed an N-allylthiocarbamoyl derivative. This reaction occurs between alanine, glycine, dipeptides (glycine-glycine, glycinealanine, alanine-glycine), tripeptides (glycine-glycineglycine and glycine-glycine-alanine), and 2-propenylisothiocyanate. The compound 2-propenyl-thiocarbamoylpeptide is formed from the reaction of 2-propenylisothiocyanate with amino acids and peptides. This reaction specifically occurs at $\mathrm{pH}$ values of 8 and 10 (Cejpek et al. 2000). Furthermore, isothiocyanate is a plant secondary metabolite hydrolyzed from glucosinolates into various derivative products, such as thiocyanates and nitrites (Liu et al. 2020). Phytochemicals are secondary metabolites found in plants that serve a variety of biological and ecological functions including protection against herbivorous insects and pathogenic microorganisms (Xue et al. 2019).

Figure 3 illustrates a unique spectrum in the negative control with wavelengths ranging from 2140 to $1990 \mathrm{~cm}^{-1}$ and is compared to other samples, as shown in Table 1. This difference provides an early indication that spectral parameters can detect $G$. boninense from palm leaf tissue (Erukhimovitch et al. 2005). Accordingly, it is evident that oil palms infected with this organism exhibit a different spectrum; hence, the pathogen can be detected or identified directly from the leaf tissue. According to Brandl. (2013), the infected biomass will produce a different FTIR compared to the healthy counterpart, owing to fungal metabolism in the plant tissues. It has been naturally tested that isothiocyanate is a synergistically efficient fungicide against pathogens that attack plants, glucosinolates of isothiocyanate derivatives exhibit high bioaccumulation potential and lipophilic properties that enable it to penetrate membranes (Dubey et al. 2021).

\section{Discussion}

The FTIR spectrum was utilized to identify functional groups of leaves that were healthy, infected, fungicidetreated, and applied with leaf extracts of D. Esculentum and R. Humilis. The wavelengths ranging from 2140 to 1990 $\mathrm{cm}^{-1}$ belonged to the isothiocyanate compound in the infected leaves of $G$. boninense. The isothiocyanate group $(\mathrm{N}=\mathrm{C}=\mathrm{S})$ is a nucleophilic group that can bind thiols, amino groups, peptides, and proteins. The inhibition of key enzymes, such as reductases, acetate kinases, and oxidases, is primarily responsible for the antifungal and antiaflatoxin effects (Nazareth et al. 2016). Isothiocyanate $(\mathrm{N}=\mathrm{C}=\mathrm{S})$ is classified as a plant organic compound, namely the metabolite unit S- $\beta$-D-glucopyranose, which is periodically related to the $\mathrm{O}$-sulfated $(\mathrm{z})$-thiohydroximate function (Cedrowski et al. 2021).

Table 1. FTIR assisted identification of functional groups in oil palm leaves

\begin{tabular}{|c|c|c|c|c|c|}
\hline \multirow{2}{*}{$\begin{array}{c}\text { Wave } \\
\text { number } \\
\left(\mathrm{cm}^{-1}\right)\end{array}$} & \multicolumn{5}{|c|}{ Functional groups } \\
\hline & KP & $\mathbf{K N}$ & DE & RE & FT \\
\hline $3300-3500$ & $\mathrm{~N}-\mathrm{H}$ (Amine) & $\mathrm{N}-\mathrm{H}$ (Amine) & $\mathrm{N}-\mathrm{H}$ (Amine) & $\mathrm{N}-\mathrm{H}$ (Amine) & $\mathrm{N}-\mathrm{H}$ (Amine) \\
\hline $2850-2970$ & C-H (Alkane) & C-H (Alkane) & C-H (Alkane) & C-H (Alkane) & C-H (Alkane) \\
\hline $2140-1990$ & & $\mathrm{~N}=\mathrm{C}=\mathrm{S}$ (Isothiocyanate) & & & \\
\hline $1610-1680$ & $\mathrm{C}=\mathrm{C}$ (Alkene) & $\mathrm{C}=\mathrm{C}($ Alkene $)$ & $\mathrm{C}=\mathrm{C}$ (Alkene) & $\mathrm{C}=\mathrm{C}$ (Alkene) & $\mathrm{C}=\mathrm{C}($ Alkene $)$ \\
\hline $1500-1600$ & $\mathrm{C}-\mathrm{C}$ (Aromatic rings) & $\mathrm{C}-\mathrm{C}$ (Aromatic rings) & $\mathrm{C}-\mathrm{C}$ (Aromatic rings) & $\mathrm{C}-\mathrm{C}$ (Aromatic rings) & $\mathrm{C}-\mathrm{C}$ (Aromatic rings) \\
\hline $1340-1470$ & C-H (Alkane) & $\mathrm{C}-\mathrm{H}$ (Alkane) & $\mathrm{C}-\mathrm{H}$ (Alkane) & $\mathrm{C}-\mathrm{H}$ (Alkane) & C-H (Alkane) \\
\hline $1180-1360$ & $\mathrm{C}-\mathrm{N}$ (Amine, Amide) & $\mathrm{C}-\mathrm{N}$ (Amine, Amide) & $\mathrm{C}-\mathrm{N}$ (Amine, Amide) & $\mathrm{C}-\mathrm{N}$ (Amine, Amide) & $\mathrm{C}-\mathrm{N}$ (Amine, Amide) \\
\hline $1050-1300$ & $\mathrm{C}-\mathrm{O}$ (Ester) & $\mathrm{C}-\mathrm{O}$ (Ester) & $\mathrm{C}-\mathrm{O}$ (Ester) & $\mathrm{C}-\mathrm{O}$ (Ester) & $\mathrm{C}-\mathrm{O}$ (Ester) \\
\hline $976-400$ & $\mathrm{C}-\mathrm{H}$ (Isoprenoids) & $\mathrm{C}-\mathrm{H}$ (Isoprenoids) & $\mathrm{C}-\mathrm{H}$ (Isoprenoids) & $\mathrm{C}-\mathrm{H}$ (Isoprenoids) & $\mathrm{C}-\mathrm{H}$ (Isoprenoids) \\
\hline
\end{tabular}

Note: Empty box indicates the absence of respective compounds in the sample. KP: Positive Control, KN: Negative control; DE: $D$. esculentum extract, RE: R. humilis extract, FT: Fungicide treatment 


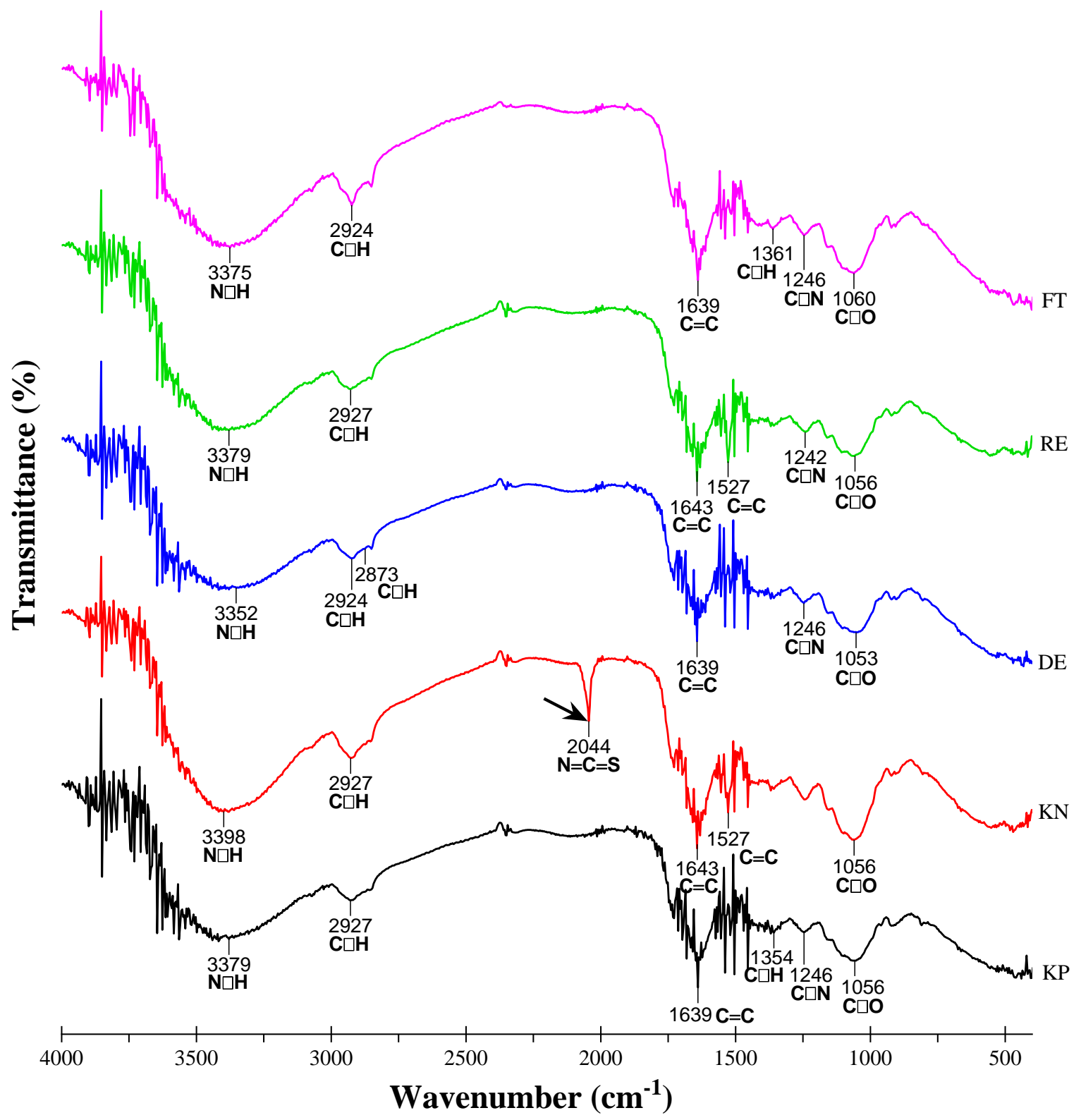

Figure 3. The $\mathrm{N}=\mathrm{C}=\mathrm{S}$ (Isothiocyanate) functional groups of infected oil palm leaves and leaf tissue in the region with $4000-400 \mathrm{~cm}^{-1}$ FTIR spectrum is healthy and infected by $D$. esculentum extract, $R$. humilis extract, and fungicides treatment

Isothiocyanate compounds are synthesized from glucosamine with acetic anhydride/pyridine that glucosamine isothiocyanate is formed through $\mathrm{N}, \mathrm{N}$ (acetyl) derivatives of phenyltiocarbamoyl glucosamine and analyzed by the FTIR at a wavelength of $2048 \mathrm{~cm}^{-1}$ derived from the $\mathrm{N}=\mathrm{C}=\mathrm{S}$ group were observed (Nishida et al. 2019). The precursor of isothiocyanate is glucosinolate ( $\beta$-thioglucoside-N-hydroxysulfates), which acts as an antifungal and several studies have proven it to be anticancer (Fahey et al. 2001). Additionally, Colletotrichum coccodes, Rhizoctonia solani, and Helminthosporium solani are diseases that infect soil-borne potato plants and isothiocyanate compounds-which are hydrolyzed from natural glucosinolates - and can inhibit fungal growth colonies in vitro based on the concentration of isothiocyanate mixed into agar (Taylor et al. 2014).

The isothiocyanates were utilized for biological, agricultural, and pharmaceutical interests for synthetic treatment and function as a strong antifungal against Candida albicans and Aspergillus niger (Chniti et al. 2020). Furthermore, isothiocyanate exhibits inhibition against fungi, nematodes, bacteria, insects, and weeds (Zhang et al. 2020). Isothiocyanate has been reported to have fungistatic and fungi toxic compounds that can control soil-borne phytopathogenic fungi (Tiznadohernández, 2008). Moreover, isothiocyanate compounds have anti-proliferative properties. For instance, a naturally occurring isothiocyanate is sulforaphane. Phenethyl isothiocyanate and benzyl isothiocyanate synthetically 
modify the atomic structure of phosphorus which has antibacterial, antifungal properties (Reagent et al. 2021). Furthermore, plants infected with $G$. boninense possessed $\mathrm{N}=\mathrm{C}=\mathrm{S}$ isothiocyanate functional group (Chen et al. 2020), which is metabolized through its conjugation to glutathione and hydrolysis into amines to fight the pathogen Sclerotinia sclerotiorum, which attacks brassicas.

The study was conducted in vitro to evaluate the efficacy of isothiocyanate with a concentration of $50 \mu \mathrm{L} / \mathrm{L}$, inhibiting the growth of the fungus Penicillium verrucosum in barley (Nazareth et al. 2019). Isothiocyanates in vitro is an antifungal compound in pears. The mechanism underlying the antifungal effect on Alternaria alternata may be through the impairment of the permeability of its cell membranes (Zhang et al. 2020). Isothiocyanate compounds operate as allelochemicals for sulfur storage, water transportation, heat tolerance, stomata regulation, apoptosis, and inhibition signaling in host plants as a defense against pests and diseases (Bones et al. 1991). According to this study, palm oil tissue can produce isothiocyanate chemicals as a defense mechanism against these infections. Furthermore, the isothiocyanate found in plants is claimed to operate as a defensive chemical released following cell tissue damage (Dose et al. 2021).

In conclusion, the FTIR spectroscopic method proved that the functional groups of different chemical compounds in infected oil palm leaf tissue contained $\mathrm{N}=\mathrm{C}=\mathrm{S}$ isothiocyanate compounds with a wave number of 2044 cm-1, compared to healthy samples, D. esculentum, R. humilis, and fungicides that were not identified. The clear and strong absorption of infrared radiation from infected samples containing the compound $\mathrm{N}=\mathrm{C}=\mathrm{S}$ isothiocyanate indicates a potential functional group as an indicator of $\mathrm{G}$. boninense infection as well as a biological marker between healthy and infected oil palms. These findings suggest that FTIR spectroscopy can be a useful tool for the early detection of diseases in oil palm plants compared to conventional methods.

\section{ACKNOWLEDGEMENTS}

The authors are grateful to the Beasiswa Unggulan Dosen Indonesia Dalam Negeri (BUDI DN) scholarship for supporting and funding this research through the Educational Fund Management Institution (LPDP). The authors are also grateful to the Ministry of Education, Culture, Research, and Technology of the Republic of Indonesia.

\section{REFERENCES}

Ahmadi P, Muharam FM, Ahmad K, Mansor S, Seman IA. 2017. Early detection of Ganoderma basal stem rot of oil palms using artificial neural network spectral analysis. Plant Dis 101: 1009-1016. DOI: 10.1094/PDIS-12-16-1699-RE.

Alexander A, Dayou J, Sipaut CS, Phin CK, Chin LP. 2014. Some interpretations on FTIR results for the detection of Ganoderma boninense in oil palm tissue. Adv Environ Biol 8: 30-32.

Alexander A, Sipaut CS, Dayou J, Chong KP. 2017. Oil palm roots colonisation by Ganoderma boninense: An insight study using scanning electron microscopy. J Oil Palm Res 29: 262-266. DOI: 10.21894/jopr.2017.2902.10.

Azmi ANN, Bejo SK, Jahari M, Muharam FM, Yule I, Husin NA. 2020. Early detection of Ganoderma boninense in oil palm seedlings using support vector machines. Remote Sens 12: 3920-3940. DOI: $10.3390 / \mathrm{rs} 12233920$.

Bahari MNA, Sakeh NM, Abdullah SNA, Ramli RR, Kadkhodaei S. 2018. Transcriptome profiling at early infection of Elaeis guineensis by Ganoderma boninense provides novel insights on fungal transition from biotrophic to necrotrophic phase. BMC Plant Biol 18: 1-26. DOI: 10.1186/s12870-018-1594-9.

Bones AM, Thangstad OP, Haugen OA, Espevik T. 1991. Fate of myrosin cells: Characterization of monoclonal antibodies against myrosinase. J Exp Bot 42: 1541-1550. DOI: 10.1093/jxb/42.12.1541.

BPS Statistics Indonesia. 2020. Indonesian Oil Palm Statistics 2019. 1155. Indonesia. https://.bps.go.id. [Indonesian]

Brandl H. 2013. Detection of fungal infection in Lolium perenne by Fourier transform infrared spectroscopy. J Plant Ecol 6: 265-269. DOI: $10.1093 /$ jpe/rts043.

Cedrowski J, Dąbrowa K, Przybylski P, Krogul-Sobczak A, Litwinienko G. 2021. Antioxidant activity of two edible isothiocyanates: Sulforaphane and erucin is due to their thermal decomposition to sulfenic acids and methylsulfonyl radicals. Food Chem 353: 129213 DOI: 10.1016/j.foodchem.2021.129213.

Chen J, Ullah C, Reichelt M, Beran F, Yang ZL, Gershenzon J, Hammerbacher A, Vassão DG. 2020. The phytopathogenic fungus Sclerotinia sclerotiorum detoxifies plant glucosinolate hydrolysis products via an isothiocyanate hydrolase. Nat Commun 11: 1-12. DOI: $10.1038 / \mathrm{s} 41467-020-16921-2$.

Chniti I, Thebti A, Sanhoury MAK, Cherif HIO, Chehidi I. 2020. Synthesis, in vitro antibacterial and antifungal activities of Trifluoroalkyl-N, N'-Disubstituted Thioureas. Org Med Chem I J 9: 121-128. DOI: 10.19080/OMCIJ.2020.09.555770.

Chong KP, Lum MS, Foong CP, Wong CMVL, Atong M, Rossall S. 2011. First identification of Ganoderma boninense isolated from Sabah based on PCR and sequence homology. Afr J Adv Biotechnol 10: 14718-14723. DOI: 10.5897/AJB11.1096.

Cooper RM, Flood J, Rees RW. 2011. Ganoderma boninense in oil palm plantations: current thinking on epidemiology, resistance and pathology. The Planter 87: 515-526.

Darus A, Seman IA. 1992. The Ganoderma selective medium (GSM). PORIM Information Series: 1-2. http://palmoilis.mpob.gov. [Malaysian]

Dose B, Niehs SP, Scherlach K, Shahda S, Flórez LV, Kaltenpoth M, Hertweck C. 2021. Biosynthesis of sinapigladioside, an antifungal isothiocyanate from Burkholderia symbionts. ChemBioChem 22: 1920-1924. DOI: 10.1002/cbic.202100089.

Dubey S, Guignard F, Pellaud S, Pedrazzetti M, van der Schuren A, Gaume A, Schnee S, Gindro K, Dubey O. 2021. Isothiocyanate derivatives of glucosinolates as efficient natural fungicides. PhytoFront 1: 40-50. DOI: 10.1094/PHYTOFR-08-20-0010-R

Erukhimovitch V, Tsror L, Hazanovsky M, Talyshinsky M. 2005. Identification of fungal phytopathogens by Fourier transform infrared (FTIR) microscopy. J Agric Sci Technol 24: 145-152. DOI: $10.1155 / 2010 / 507295$.

Fahey JW, Zalcmann AT, Talalay P. 2001. The chemical diversity and distribution of glucosinolates and isothiocyanates among plants. Phytochemistry 56: 5-51. DOI: 10.1016/S0031-9422(00)00316-2.

Gaoqiang L, Changwen D, Fei M, Yazhen S, Jianmin Z. 2020. Responses of leaf cuticles to rice blast: Detection and identification using depthprofiling Fourier transform mid-infrared photoacoustic spectroscopy. Plant Dis 104: 847-852. DOI: 10.1094/PDIS-05-19-1004-RE.

Goh KM, Dickinson M, Alderson P, Yap LV, Supramaniam CV. 2016. Development of an in planta infection system for the early detection of Ganoderma spp. in oil palm. J Plant Pathol 98: 255-264. DOI: 10.4454/JPP.V98I2.019.

Hashim IC, Shariff ARM, Bejo SK, Muharam FM, Ahmad K. 2021. Machine learning approach using SAR data for the classification of oil palm trees that are non-infected and infected with basal stem rot disease. Agronomy 11: 532-548. DOI: 10.3390/agronomy11030532.

Hayati R, Basyuni M. 2019. Sequence approach of Elaeis guineensis for early detection of Ganoderma boninense resistance. IOP Conference Series: J Earth Environ Sci 260: 2127-2131. DOI: 10.1088/17551315/260/1/012127.

Husin NA, Khairunniza-Bejo S, Abdullah AF, Kassim MSM, Ahmad D, Aziz MHA. 2020. Classification of basal stem rot disease in oil palm 
plantations using terrestrial laser scanning data and machine learning. Agronomy 10: 1624-1646. DOI: 10.3390/agronomy10111624.

Idris AS, Kushairi D, Ariffin D, Basri MW. 2006. Technique for inoculation of oil palm germinated seeds with Ganoderma. МРOB Infomation Series 314: 1-4. http://palmoilis.mpob.gov. [Malaysian]

Isha A, Akanbi FS, Yusof NA, Osman R, Mui-Yun W, Abdullah SNA 2019. An NMR metabolomics approach and detection of Ganoderma boninense infected oil palm leaves using MWCNT-based electrochemical sensor. J Nanomater 47: 706-717. DOI: 10.1155/2019/4729706.

Janczewski L, Kregiel D, Kolesinska B. 2021. Synthesis of isothiocyanates using $\mathrm{DMT} / \mathrm{NMM} / \mathrm{TsO}^{-}$as a new desulfurization reagent. Molecules 26: 2740-2763. DOI: 10.3390/molecules26092740.

Junaedi D. 2020. Data dan fakta sawit Indonesia : Luas, sebaran dan tantangannya. Webinar; Ngopini Sawit \#2. Jakarta, 24 Juni 2020. www.auriga.or.id [Indonesian]

Kandan A, Radjacommare R, Ramanathan A, Raguchander T, Balasubramanian P, Samiyappan R. 2009. Molecular biology of Ganoderma pathogenicity and diagnosis in coconut seedlings. Folia Microbiol 54: 147-152. DOI: 10.1007/s12223-009-0022-9.

Kavitha A, Mary Kensa V. 2020. GC-MS Analysis of the whole plant ethanolic extract of the Rivina humilis L. J Inf Comput Sci 10: 553559.

Kayalvizhi V, Antony U. 2011. Microbial and physicochemical changes in tomato juice subjected to pulsed electric field treatment. Afr J Agric Res 6: 6348-6353. DOI: 10.5897/A

Khan AL, Al-Harrasi A, Numan M, Abdulkareem NM, Mabood F, AlRawahi A. 2021. Spectroscopic and molecular methods to differentiate gender in immature date palm (Phoenix dactylifera L.). Plants 10: 536-550. DOI: 10.3390/plants10030536.

Lai DS, Osman AF, Adnan SA, Ibrahim I, Alrashdi AA, Salimi MNA, UlHamid A. 2021. On the use of OPEFB derived microcrystalline cellulose and nano bentonite for development of thermoplastic starch hybrid bio-composites with improved performance. Polymers 13 897-918. DOI: 10.3390/polym13060897.

Liaghat S, Mansor S, Ehsani R, Shafri HZM, Meon S, Sankaran S. 2014 Mid-infrared spectroscopy for early detection of basal stem rot disease in oil palm. Comput Electron Agric 101:48-54. DOI: 10.1016/j.compag.2013.12.012

Midot F, Lau SYL, Wong WC, Tung HJ, Yap ML, Lo ML, Jee MS, Dom SP, Melling L. 2019. Genetic diversity and demographic history of Ganoderma boninense in oil palm plantations of Sarawak, Malaysia inferred from ITS regions. Microorganisms 7: 464-480. DOI: 10.3390/microorganisms 7100464 .

Ministry of Agriculture. 2019. Tree crop estate statistics of Indonesia 2018-2020: Palm Oil. Secretariate of Directorate General of Estates: 1-82. [Indonesian]

Mitsiogianni M, Koutsidis G, Mavroudis N, Trafalis DT, Botaitis S, Franco R, Zoumpourlis V, Amery T, Galanis A, Pappa A, Panayiotidis MI 2019. The role of isothiocyanates as cancer anti-melanoma agents Antioxidants 8: 106-137. DOI: 10.3390/antiox8040106.

Mohd Najib NE, Kanniah KD, Cracknell AP, Yu L. 2020. Synergy of active and passive remote sensing data for effective mapping of oi palm plantation in Malaysia. Forests 11: 858-881. DOI 10.3390/F11080858.

Nazareth T de M, Bordin K, Manyes L, Meca G, Manes J, Luciano F B 2016. Gaseous allyl isothiocyanates to inhibit the production of aflatoxins, beauvericin and enniatins by Aspergillus parasiticus and Fusarium poae in wheat flour. Food Control 62: 317-321. DOI: 10.1016/j.foodcont.2015.11.003

Nazareth T de M, Quiles JM, Torrijos R, Luciano FB, Mañes J, Meca G. 2019. Antifungal and antimycotoxigenic activity of allyl isothiocyanate on barley under different storage conditions. Food Sci Technol 112: 108237. DOI: 10.1016/j.lwt.2019.06.004.

Nishida S, Shibano M, Kamitakahara H, Takano T. 2019. Basic study for acyl chitosan isothiocyanates synthesis by model experiments using glucosamine derivatives. Int $\mathbf{J}$ Biol Macromol 132: 17-23. DOI: 10.1016/j.ijbiomac.2019.03.114

Penido A, Mendes P, Campos I, Mendes L. 2013. Effect of various media and supplements on laccase activity and its application in dyes decolorization. Malays J Microbiol 9: 166-175. DOI 10.21161/mjm.47712.

Priwiratama H, Prasetyo AE, Susanto A. 2020. Incidence of basal stem rot disease of oil palm in converted planting areas and control treatments. IOP Conference Series: J Earth Environ Sci. 468: 2036-2042. DOI: $10.1088 / 1755-1315 / 468 / 1 / 012036$
Purba A, Hayati R, Putri LAP, Chalil D, Afandi D, Syahputra I, Basyuni M. 2020. Genetic diversity and structure of Ganoderma boninense isolates from oil palm and other plantation crops. Biodiversitas 21: 451-456. DOI: 10.13057/biodiv/d210204

Rahamah MSH, Paiko AS, Khairulmazmi A, Akhtar MS, Idris AS. 2016. Control of basal stem rot disease in oil palm by supplementation of calcium, copper, and salicylic acid. Plant Pathol J 32: 396-406. DOI: 10.5423/PPJ.OA.03.2016.0052.

Rakib MRM, Bong CFJ, Khairulmazmi A, Idris AS. 2014. Genetic and morphological diversity of Ganoderma species isolated from infected oil palms (Elaeis guineensis). Int J Agric Biol 16: 691-699.

Rattanata N, Daduang S, Phaetchanla S, Bunyatratchata W, Promraksa B, Tavichakorntrakool R, Uthaiwat P, Boonsiri P, Daduang J. 2014. Antioxidant and antibacterial properties of selected Thai weed extracts. Asian Pac J Trop Biomed 4: 890-895. DOI: 10.12980/APJTB.4.2014APJTB-2014-0422.

Rebitanim NA, Hanafi MM, Idris AS, Abdullah SNA, Mohidin H, Rebitanim NZ. 2020. GanoCare $®$ improves oil palm growth and resistance against Ganoderma basal stem rot disease in nursery and field trials. BioMed Res Int 2020: 3063710. DOI: 10.1155/2020/3063710.

Said N, Omar D, Nasehi A, Wong MY. 2019. Pyraclostrobin suppressed Ganoderma basal stem rot (BSR), promoted plant growth and induced early expression of $\beta-1,3$-glucanase in oil palm (Elaeis guineensis). $\mathbf{J}$ Oil Palm Res 31: 248-261. DOI: 10.21894/jopr.2019.0021.

Salman A, Tsror L, Pomerantz A, Moreh R, Mordechai S, Huleihel M. 2010. FTIR spectroscopy for detection and identification of fungal phytopathogens. Spectroscopy 24: 261-267. DOI: 10.3233/SPE-20100448 .

Saragih WS, Purba E. 2018. Identification and analysis of weed vegetation as Ganoderma presence marker on oil palm plantation. Natural 18: 135-140. DOI: 10.24815/jn.v0i0.11595. [Indonesian]

Saragih WS, Purba E. 2019. Analisis Hara Cu dan Zn pada vegetasi gulma sebagai penanda keberadaan jamur Ganoderma dari kebun kelapa sawit. J Agrotek Tropika 7: 519-525. DOI: 10.23960/jat.v7i3.3237. [Indonesian]

Siddiqui Y, Surendran A, Paterson RRM, Ali A, Ahmad K. 2021. Current strategies and perspectives in detection and control of basal stem rot of oil palm. Saudi J Biol Sci 28: 2840-2849. DOI: 10.1016/j.sjbs.2021.02.016.

Suprapta DN. 2016. A review of tropical plants with antifungal activities against plant fungal pathogens. Preprints: 1-13. DOI: 10.20944/preprints201610.0049.v1.

Susanto A. 2011. Informasi organisme pengganggu tanaman: Penyakit busuk pangkal batang Ganoderma boninense Pat. Pusat Penelitian Kelapa Sawit P-0001: 1-4. [Indonesian]

Taylor FI, Kenyon D, Rosser S. 2014. Isothiocyanates inhibit fungal pathogens of potato in in vitro assays: Isothiocyanates produced by Brassica spp. inhibit growth of three economically important potato pathogens. Plant Soil 382: 281-289. DOI: 10.1007/s11104-014-2157-y.

Tiznado-hernández ME. 2008. Control of fungal diseases with isothiocyanates. Stewart Postharvest Rev 2: 1-14. DOI: 10.2212/spr.2006.1.4.

Tongco JVV, Villaber RAP, Aguda RM, Razal RA. 2014. Nutritional and phytochemical screening, and total phenolic and flavonoid content of Diplazium esculentum (Retz.) Sw. from Philippines. J Chem Pharm Res 6: 238-242.

Utomo C, Niepold F. 2000. Development of diagnostic methods for detecting Ganoderma infected oil palms. J Phytopathol 148: 507-514. DOI: 10.1046/j.1439-0434.2000.00478.x.

Viera-Torres M, Sinde-González I, Gil-Docampo M, Bravo-Yandún V, Toulkeridis T. 2020. Generating the baseline in the early detection of bud rot and red ring disease in oil palms by geospatial technologies. Remote Sens 12: 3229-3249. DOI: 10.3390/rs12193229.

Westworth S, Ashwath N, Cozzolino D. 2019. Application of FTIR-ATR spectroscopy in the Beauty Leaf Tree (Calophyllum inophyllum L.) Energy Procedia 160: 761-768. DOI: 10.1016/j.egypro.2019.02.182.

Xue H, Jiang Y, Zhao H, Köllner TG, Chen S, Chen F. 2019. Characterization of composition and antifungal properties of leaf secondary metabolites from thirteen cultivars of Chrysanthemum morifolium Ramat. Molecules 24: 4202-4212. DOI: $10.3390 /$ molecules 24234202 .

Zhang M, Li Y, Bi Y, Wang T, Dong Y, Yang Q, Zhang T. 2020. 2Phenylethyl isothiocyanate exerts antifungal activity against Alternaria alternata by affecting membrane integrity and mycotoxin production. Toxins 12: 124-136. DOI: 10.3390/toxins12020124. 